\title{
Effect of Potential on Structural, Morphological and Optical Properties of ZnO Thin Films Obtained by Electrodeposition
}

\author{
Ayça Kıyak Yıldırım* and Barış Altıokka \\ Bilecik Vocational School of Higher Education, Bilecik Şeyh Edebali University, Bilecik 11210, Turkey
}

\begin{abstract}
Polycrystal $\mathrm{ZnO}$ thin films have been deposited on ITO coated glass substrate in two different potential of $-0.85 \mathrm{~V}$ and -0.95 $\mathrm{V}$ by electrochemical deposition technique using $0.005 \mathrm{M} \mathrm{ZnCl}_{2}$ or $0.01 \mathrm{M}\left(\mathrm{Zn}\left(\mathrm{NO}_{3}\right)_{2} \cdot 6 \mathrm{H}_{2} \mathrm{O}\right)$ at $72 \pm 2{ }^{\circ} \mathrm{C}$ and with supporting electrolyte $0.1 \mathrm{M} \mathrm{KCl}$ aqueous solutions. Before the depositions, the solutions were saturated with oxygen by passing oxygen through the growth cell. The energy band gaps of the obtained films were estimated from the absorbance measurements. The energy band gaps of the films obtained using $\mathrm{Zn}\left(\mathrm{NO}_{3}\right)_{2}$ were between 3.49 and $3.57 \mathrm{eV}$ while that of obtained using $\mathrm{ZnCl}_{2}$ were between 3.60 and $3.63 \mathrm{eV}$. XRD (X-ray diffraction) results showed that all the films have a hexagonal structure. It was obtained by XRD that the crystallite sizes of the films are between 46 and $54 \mathrm{~nm}$. Morphological characterization of the $\mathrm{ZnO}$ thin films was characterized from the SEM (Scanning electron microscopy) images. It is seen from the SEM images that the surface of the films are leafy and flaky form.
\end{abstract}

Key words: ZnO, electrochemical deposition, different potential, SEM (Scanning electron microscopy).

\section{Introduction}

Over the last few years, $\mathrm{ZnO}$ films have been growing and investigated because of their good optical and electrical characteristics and their transparency in the visible wavelength [1].

$\mathrm{ZnO}$ exhibit n-type feature [2] and its optical band gap vary from 3.2 to $3.4 \mathrm{eV}$ at room temperature [3]. $\mathrm{ZnO}$ is direct band gap and it has relatively large exciton binding energy of $60 \mathrm{mV}$ [4]. Zinc oxide exists in three forms as to be cubic zincblende, hexagonal wurtzite and rarely in cubic rocksalt structures. The most common structure is wurtzite and the zincblende form which can be stabilized by growing $\mathrm{ZnO}$ on substrates with cubic lattice structure. The rocksalt structure only form at high pressure of nearly $10 \mathrm{GPa}$ [5].

A variety of techniques are used to deposit $\mathrm{ZnO}$ thin films such as metal organic chemical vapour deposition [6] RF magnetron sputtering [7, 8], pulsed

\footnotetext{
*Corresponding author: Ayça Kıyak Yıldırım, post graduate, research field: electrodeposition. E-mail: ayca.kiyak@bilecik.edu.tr.
}

laser deposition [9], molecular beam epitaxy [10] spray pyrolysis [11], sol-gel [12] and electrodeposition with using aqueous solutions [13-16]. Among these techniques, the electrodeposition method has many advantages that is less onerous and widely used in industry. It is a low-temperature processing usually most of the deposits were carried under a temperature below $100{ }^{\circ} \mathrm{C}$, which allows various substrate shapes and a controllable film thickness [1]. In addition to them, the morphology of the grown oxide varied much in grains size and shape from single nanobelts, nanowires [17], nanocolumns [18] and nanorods [19].

There are two ways to electrodeposit $\mathrm{ZnO}$ films such as cyclic voltamperometry which is an useful for analytical purposes and potentiostatic technique (chronoamperometry) for $\mathrm{ZnO}$ films elaboration.

\section{Experimental Details}

Polycrystal $\mathrm{ZnO}$ thin films were produced by electrodeposition from aqueous solutions composed of $5 \times 10^{-2} \mathrm{M} \mathrm{ZnCl}_{2}$ with supporting electrolyte $0.1 \mathrm{M}$ $\mathrm{KCl}$ or $1 \times 10^{-2} \mathrm{M} \mathrm{Zn}\left(\mathrm{NO}_{3}\right)_{2} \cdot 6 \mathrm{H}_{2} \mathrm{O}$ and with supporting 
electrolyte $0.1 \mathrm{M} \mathrm{KCl}$. Before the film deposition, the ITO substrates and deposition cell were washed acetone and then rinsed with deionized water. The rinsed deposition cell and the ITO substrates were left to dry at room conditions. The final solutions temperature was held at $72 \pm 2{ }^{\circ} \mathrm{C}$. Before the depositions aqueous solutions were saturated with oxygen by passing oxygen through the growth cell for $40 \mathrm{~min}$. IVIUM VERTEX Potentiostat/Galvanostat system with conventional three electrode cell was used for film deposition with ITO glass substrate having a sheet resistance of $25 \Omega / \mathrm{cm}$ as the working electrode with an effective deposition area of $1.65 \mathrm{~cm}^{2}$. A platinum sheet was used as the counter electrode and an $\mathrm{Ag} / \mathrm{AgCl}$ saturated electrode was used as the reference electrode to electrodeposition of $\mathrm{ZnO}$ thin films. Electrodepositions were carried out potentio statically without stirring at different cathodic potentials $-0.85 \mathrm{~V}$ and $-0.95 \mathrm{~V}$ (versus $\mathrm{Ag} / \mathrm{AgCl}$ ) for $30 \mathrm{~min}$ in order.

The $\mathrm{pH}$ of aqueous solutions measured to be 6.29. Optical absorption spectrums of the obtained $\mathrm{ZnO}$ thin films were obtained between $300 \mathrm{~nm}$ and $600 \mathrm{~nm}$ range by JASCO V-530 UV-Vis double beam spectrometer. Surface morphology of $\mathrm{ZnO}$ thin films and $\mathrm{Zn} / \mathrm{O}$ ratios was investigated by the scanning electron microscope ZEISS SUPRA 40 VP with coated platinum. XRD (X-ray diffraction) patterns of the films were recorded with a PANALYTICAL EMPYREAN high temperature X-ray diffractometer using $\mathrm{Cu} \quad \mathrm{K} \alpha$ radiation $(\lambda \mathrm{K} \alpha=1.5418 \AA)$ and the diffraction patterns of the $\mathrm{ZnO}$ thin films were recorded as a function of $2 \theta$ angle.

\section{Results and Discussion}

\subsection{Structural Properties of ZnO Films}

Fig. 1 shows the XRD patterns of the electrodeposited $\mathrm{ZnO}$ thin films. It is seen from the Fig. 1 that all of the $\mathrm{ZnO}$ film have strong (002) preferred orientation. It is also seen from the Fig. 1 that the (002) peak intensity of the $\mathrm{ZnO}$ thin films obtained with using $\mathrm{ZnCl}_{2}$ are higher than obtained with using
$\mathrm{Zn}\left(\mathrm{NO}_{3}\right)_{2} \cdot 6 \mathrm{H}_{2} \mathrm{O}$ at $-0.85 \mathrm{~V}$. Moreover, the ratio of the (002) peak intensity to the (011) peak intensity of the $\mathrm{ZnO}$ thin films which were obtained $-0.85 \mathrm{~V}$ zinc nitrate, $-0.95 \mathrm{~V}$ zinc nitrate, $-0.85 \mathrm{~V}$ zinc chloride and $-0.95 \mathrm{~V}$ zinc chloride are $3.33,23.04,13.28,67.85$, respectively. Moreover, XRD results showed that all of the films have a hexagonal structure.

The crystallite sizes of the $\mathrm{ZnO}$ films were calculated by measuring the full-width at half-maximum of the (002) peak using the following Scherrer formula:

$$
c s=\frac{K \lambda}{B \cos \theta}
$$

Where, $c s$ is the crystallite size, $K$ is the constant, $\lambda$ is the wavelength of X-ray radiation (1.54 $\AA$ ), $B$ is the full width at the half maximum of peak height and $\theta$ is the Bragg's angle [20]. The calculated crystallite sizes are given in Table 1. The crystallite sizes were found to be

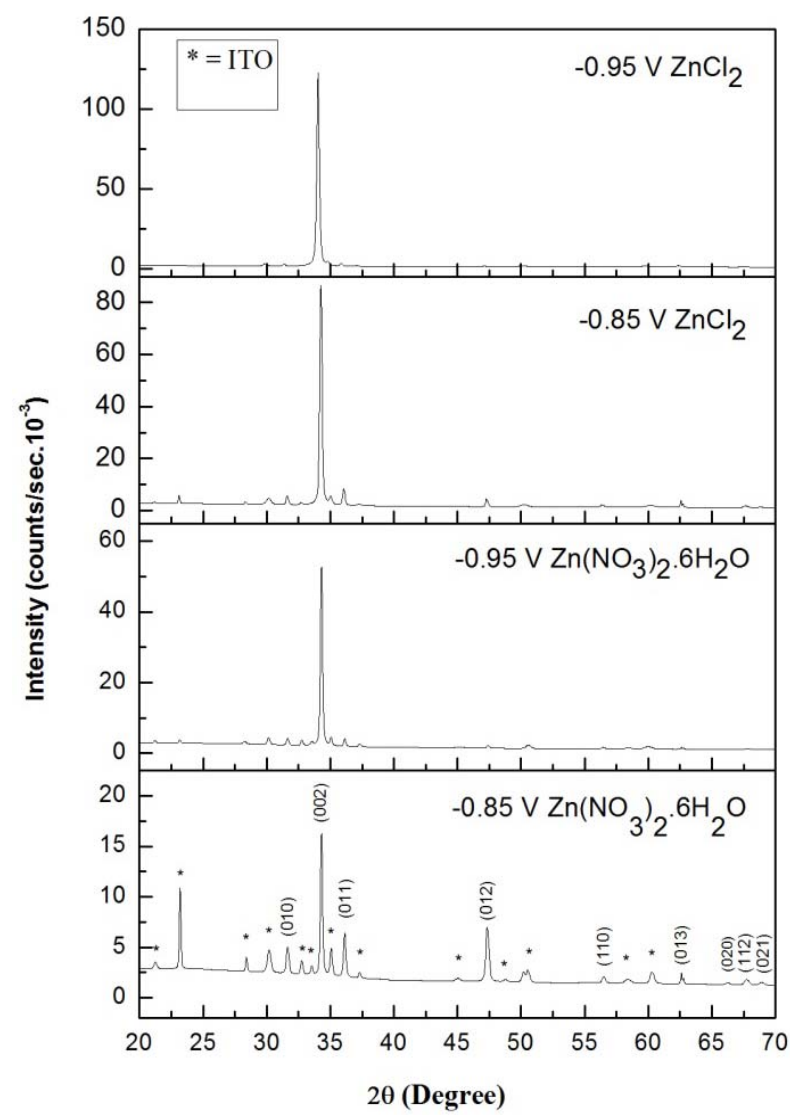

Fig. 1 The XRD patterns of the $\mathrm{ZnO}$ films that obtained in zinc nitrate at $\mathbf{- 0 . 8 5} \mathrm{V}$ and at $\mathbf{- 0 . 9 5} \mathrm{V}$, in zinc chloride at $\mathbf{- 0 . 8 5}$

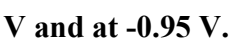

between 46 and $54 \mathrm{~nm}$. The crystallite sizes of the $\mathrm{ZnO}$ 
films obtained using $\mathrm{Zn}\left(\mathrm{NO}_{3}\right)_{2} \cdot 6 \mathrm{H}_{2} \mathrm{O}$ have bigger than the obtained using $\mathrm{ZnCl}_{2}$.

The thicknesses of the obtained films were calculated applying following Faraday's law:

$$
t=\frac{1}{n F A}\left(\frac{Q M}{\rho}\right)
$$

Where, $n$ is the number of electrons transferred, $F$ is Faraday's number, $A$ is the electrode area, $Q$ is the accumulated charge during the electrodeposition, $M$ is the formula weight $(81.4 \mathrm{~g} / \mathrm{mol})$ and $\rho$ is the density $\left(5.6 \mathrm{~g} / \mathrm{cm}^{3}\right)$ [21]. The calculated film thicknesses are given in Table 2. With regard to the film thicknesses, the $\mathrm{ZnO}$ films obtained using $\mathrm{Zn}\left(\mathrm{NO}_{3}\right)_{2} \cdot 6 \mathrm{H}_{2} \mathrm{O}$ at

$-0.95 \mathrm{~V}$ have thicker than the obtained using $\mathrm{ZnCl}_{2}$ at $-0.95 \mathrm{~V}$.

\subsection{Optical Properties of ZnO Films}

The absorbance spectra of the $\mathrm{ZnO}$ films are shown in Fig. 2. It was seen from the Fig. 2 that the $\mathrm{ZnO}$ films obtained in using $\mathrm{Zn}\left(\mathrm{NO}_{3}\right)_{2} \cdot 6 \mathrm{H}_{2} \mathrm{O}$ at $-0.85 \mathrm{~V}$ and at $-0.95 \mathrm{~V}$ have a high absorbance while the obtained in using $\mathrm{ZnCl}_{2}$ at $-0.85 \mathrm{~V}$ and at $-0.95 \mathrm{~V}$ have low absorbance.

The transmittances versus wavelength plot are shown in Fig. 3. It was attracted attention in the Fig. 3 that the films obtained with Zink chloride demonstrate average $20 \%$ transmittance while the films obtained with Zink nitrate demonstrate average $7 \%$ transmittance at the $500 \mathrm{~nm}$ of wavelength.

For the thin film materials, a Tauc plot is used to estimate the optical energy band gap. The Tauc theory is expressed by Eq. 3 [22]:

$$
(\alpha h v)^{1 / m}=A\left(h v-E_{g}\right)
$$

Where, $A$ is a constant, $E_{g}$ is the energy band gap and $\mathrm{m}$ is $1 / 2$ and $3 / 2$, for an allowed direct energy gap and a forbidden direct energy gap, respectively [22]. For the $\mathrm{ZnO}$ films, $\mathrm{m}$ is $1 / 2 . E_{g}$ was estimated from the $(\alpha h v)^{2}$ vs $(h v)$ plot, which is given in Fig. 4. The energy band gaps of $\mathrm{ZnO}$ films varied between 3.49 and $3.63 \mathrm{eV}$. The energy band gaps of $\mathrm{ZnO}$ films obtained using zinc chloride are more than the energy band gaps of the films obtained using zinc nitrate.

The reflectance of the films are shown in Fig. 5. It is shown in Fig. 5 that the reflectance of the films obtained using zinc chloride demonstrate about half of the reflectance of the films obtained using zinc nitrate.

\subsection{Surface Morphology of ZnO Thin Films}

Fig. 5 shows the surface morphologies of $\mathrm{ZnO}$ films prepared at different cathodic potentials. The surface of the $\mathrm{ZnO}$ films prepared using zinc nitrate at $-0.85 \mathrm{~V}$ (Fig. 6a) has more flakes than that of using zinc chloride at $-0.85 \mathrm{~V}$ (Fig. 6b). Also, the $\mathrm{ZnO}$ films prepared using zinc chloride at $-0.85 \mathrm{~V}$ formed leafy morphology. The flakes on the surface of the $\mathrm{ZnO}$ film prepared using zinc nitrate at $-0.95 \mathrm{~V}$ (Fig. 6c) are quite increased and almost covered with the entire surface of the $\mathrm{ZnO}$ film. The flakes on the surface of the $\mathrm{ZnO}$ film

Table 1 The calculated crystallite sizes of the $\mathrm{ZnO}$ thin films.

\begin{tabular}{lllllll}
\hline Aqueous solutions compose & $\begin{array}{l}\text { Supporting } \\
\text { electrolyte }\end{array}$ & $\begin{array}{l}\text { Cathodic } \\
\text { potentials (V) }\end{array}$ & FWHM & Intensity & $2 \theta$ & Crystallite size (nm) \\
\hline \multirow{2}{*}{$1 \times 10^{-2} \mathrm{M} \mathrm{Zn}\left(\mathrm{NO}_{3}\right)_{2} \cdot 6 \mathrm{H}_{2} \mathrm{O}$} & & -0.85 & 0.1535 & $11,646.21$ & 34.2867 & 53.5 \\
& & -0.95 & 0.1535 & $41,946.69$ & 34.2855 & 53.5 \\
\multirow{2}{*}{$5 \times 10^{-2} \mathrm{M} \mathrm{ZnCl}_{2}$} & & -0.85 & 0.1791 & $66,113.07$ & 34.2387 & 45.9 \\
& & -0.95 & 0.1791 & $92,253.67$ & 34.0155 & 45.9 \\
\hline
\end{tabular}

Table 2 The calculated film thicknesses of the $\mathrm{ZnO}$ thin films.

\begin{tabular}{llllll}
\hline Aqueous solutions compose & $\begin{array}{l}\text { Supporting } \\
\text { electrolyte }\end{array}$ & $\begin{array}{l}\text { Cathodic } \\
\text { potentials (V) }\end{array}$ & Deposition time (s) & Current (mA) & Film thicknesses (nm) \\
\hline \multirow{2}{*}{$1 \times 10^{-2} \mathrm{M} \mathrm{Zn}\left(\mathrm{NO}_{3}\right)_{2} \cdot 6 \mathrm{H}_{2} \mathrm{O}$} & & -0.85 & 1,800 & -2.104 & 1,806 \\
& \multirow{2}{*}{$0.1 \mathrm{M} \mathrm{KCl}$} & -0.95 & 1,800 & -4.431 & 3,803 \\
\multirow{2}{*}{$5 \times 10^{-2} \mathrm{M} \mathrm{ZnCl}_{2}$} & & -0.85 & 1,800 & -2.321 & 1,991 \\
& & -0.95 & 1,800 & -2.164 & 1,858 \\
\hline
\end{tabular}




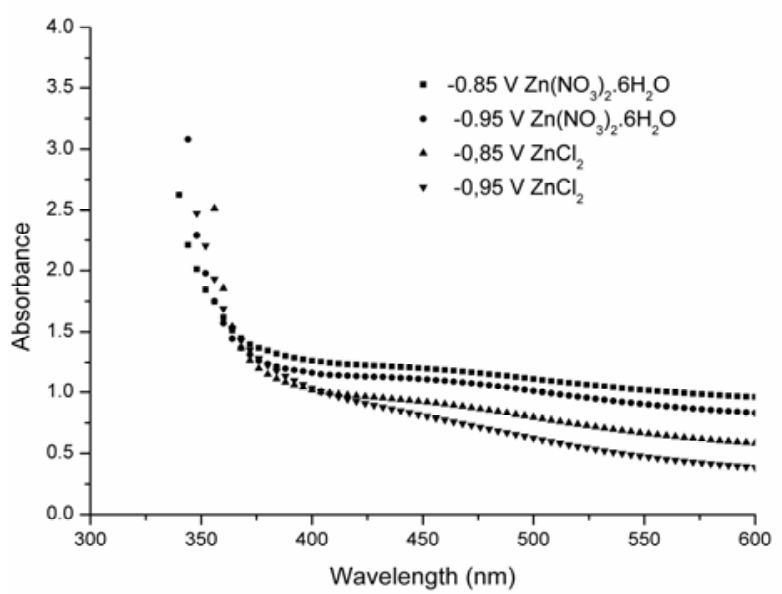

Fig. 2 Optical absorption spectra of the $\mathrm{ZnO}$ films obtained in zinc nitrate at $-0.85 \mathrm{~V}$ and at $-0.95 \mathrm{~V}$, in zinc chloride at $-0.85 \mathrm{~V}$ and at $-0.95 \mathrm{~V}$, the wavelength range from 300 to $600 \mathrm{~nm}$.

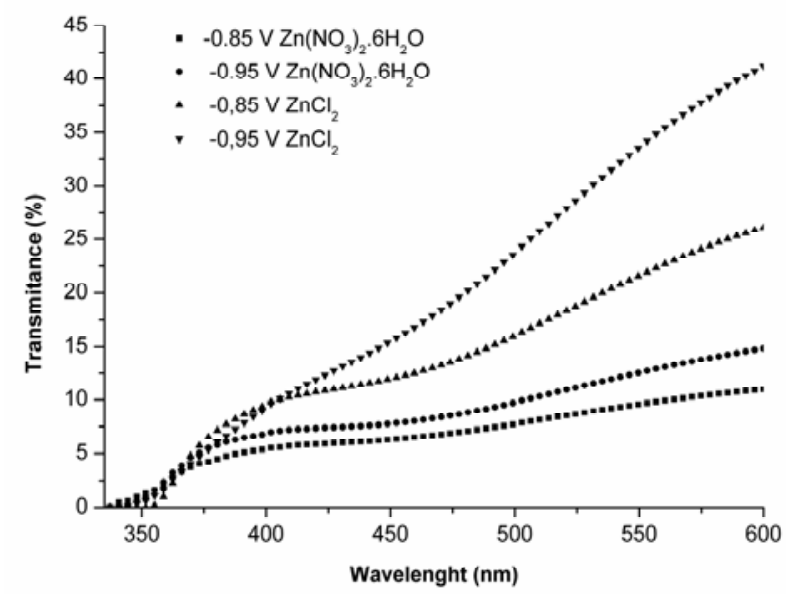

Fig. 3 Transmittances vs. wavelength plot of the obtained films.

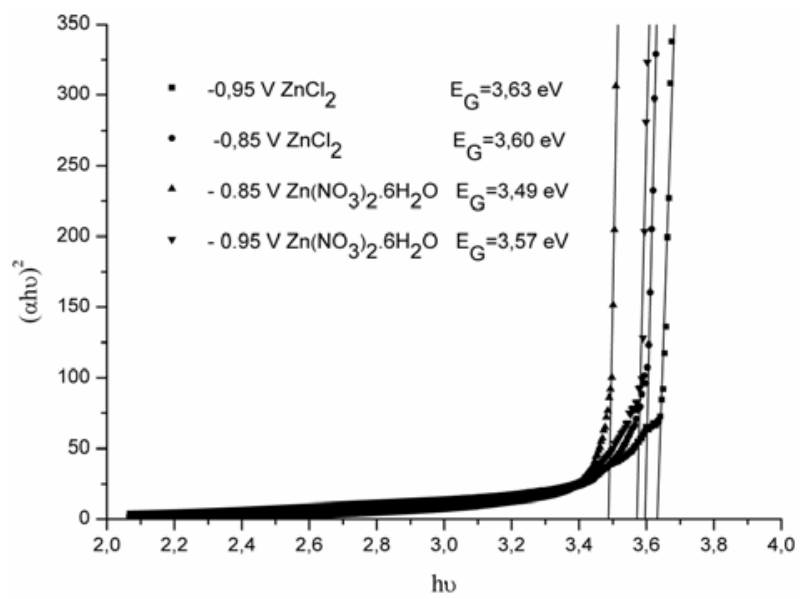

Fig. 4 Plots of $(\alpha h v)^{2}$ vs (hv) for the $\mathrm{ZnO}$ films.

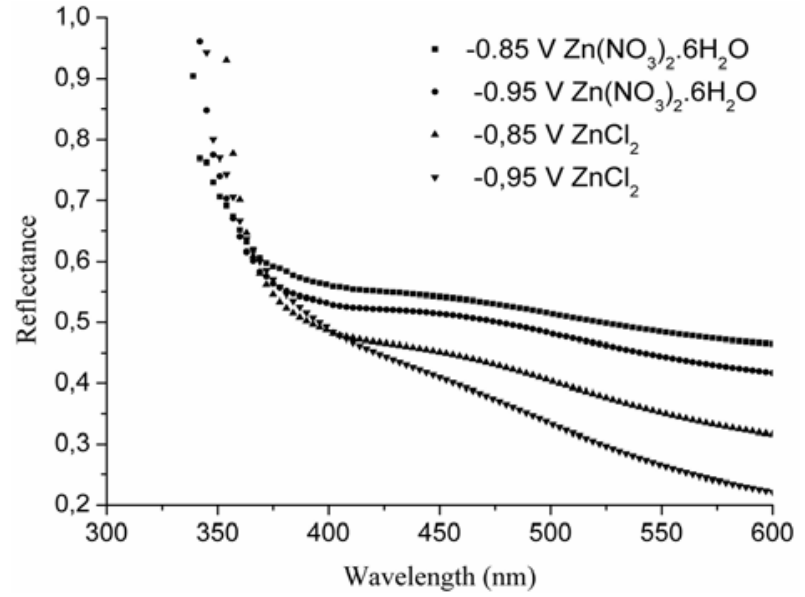

Fig. 5 Plots of reflectance versus wavelength.

prepared using zinc chloride at $-0.95 \mathrm{~V}$ almost disappeared and the entire surface of the $\mathrm{ZnO}$ film is full of leafy nanoforms with diameters about $202 \mathrm{~nm}$ as is seen in Fig. 6d.

\section{Conclusions}

In this study, we report the effect of potential on the growth and properties of electrodeposited zinc oxide films from using $5 \times 10^{-2} \mathrm{M} \mathrm{ZnCl}_{2}$ or $1 \times 10^{-2} \mathrm{M}$ $\mathrm{Zn}\left(\mathrm{NO}_{3}\right)_{2} \cdot 6 \mathrm{H}_{2} \mathrm{O}$ at $72 \pm 2{ }^{\circ} \mathrm{C}$ and with supporting electrolyte $0.1 \mathrm{M} \mathrm{KCl}$ aqueous solutions on ITO substrates. The differences that occurred in the structural, optical and morphological were also seen. According to XRD results, the (002) peak intensity of the $\mathrm{ZnO}$ thin films obtained with zinc chloride are higher average 3.19 times than that of the obtained films with zinc nitrate. With regard to the transmittance spectra of the $\mathrm{ZnO}$ films obtained in using zinc nitrate at $-0.85 \mathrm{~V}$ and at $-0.95 \mathrm{~V}$ are lower average 3 times than that of the films obtained with using zinc chloride at $-0.85 \mathrm{~V}$ and at $-0.95 \mathrm{~V}$. Additionally, the energy band gaps of $\mathrm{ZnO}$ films obtained using zinc nitrate at $-0.85 \mathrm{~V}$ and using zinc chloride at $-0.85 \mathrm{~V}$ have about the same. Optical band gap of $\mathrm{ZnO}$ varies naturally from 3.2 to $3.4 \mathrm{eV}$ at room temperature [23]. But $\mathrm{ZnO}$ film having $3.63 \mathrm{eV}$ energy band gap could be produced in this study. The surface morphologies of $\mathrm{ZnO}$ films prepared at different cathodic potentials were investigated 


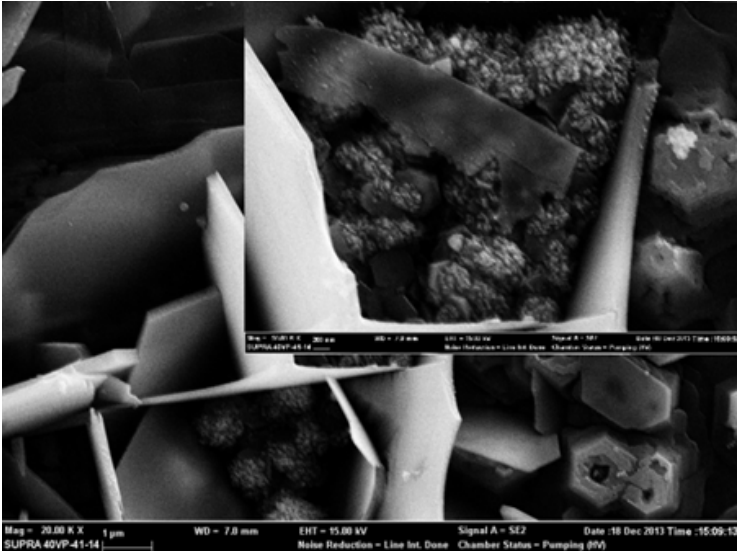

(a)

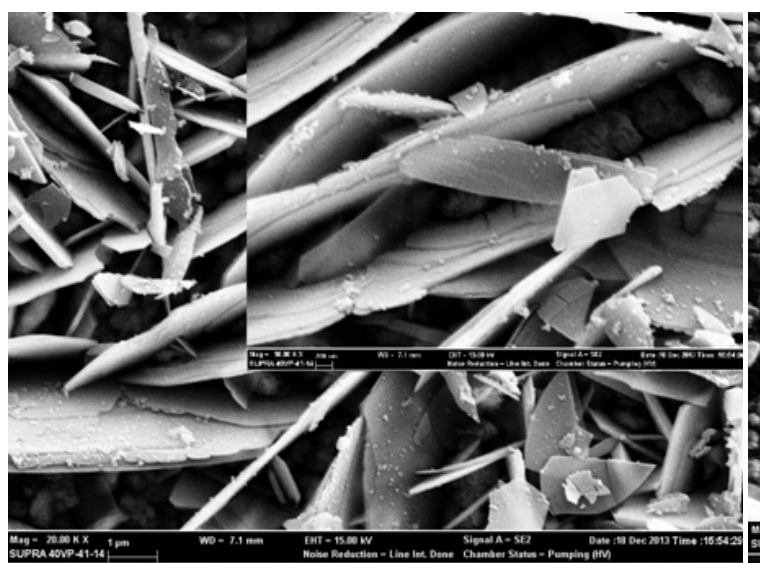

(c)

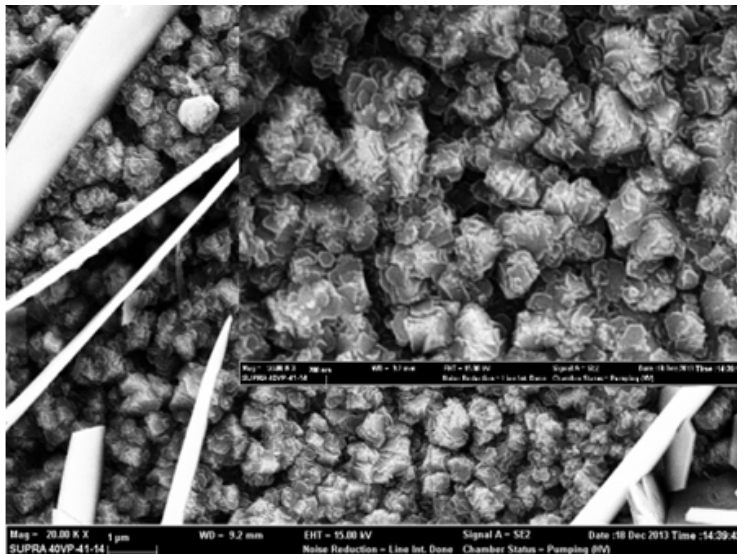

(b)

Fig. 6 Relatively low (20,000X) and high (50,000X) magnification top-view SEM images of ZnO films obtained in (a) zinc nitrate at $\mathbf{- 0 . 8 5} \mathrm{V}$, (b) zinc chloride at $\mathbf{- 0 . 8 5} \mathrm{V}$, (c) zinc nitrate at $\mathbf{- 0 . 9 5} \mathrm{V}$ and (d) zinc chloride at $\mathbf{- 0 . 9 5} \mathrm{V}$.

by using SEM (Scanning electron microscopy). The surface of the $\mathrm{ZnO}$ film prepared using zinc nitrate exhibit flaky morphology. Also, the $\mathrm{ZnO}$ film having leafy grain morphology could be obtained by using zinc chloride at $-0.95 \mathrm{~V}$.

\section{References}

[1] Chettah, H. and Abdi, D. 2013. "Effect of the Electrochemical Technique on Nanocrystalline $\mathrm{ZnO}$ Electrodeposition, Its Structural, Morphological and Photoelectrochemical Properties.” Thin Solid Films 537: 119-23.

[2] Hou, Q., Zhu, L., Chen, H., Liu, H. and Li, W. 2012. "Growth of Porous $\mathrm{ZnO}$ Nanosheets by Electrodeposition with the Addition of $\mathrm{KBr}$ in Nitrate Electrolyte." Mater. Lett. 89: 283-6.

[3] Kathalingam, A., Kim, M. R., Chae, Y. S. and Rhee, J. K. 2009. "Studies on Electrochemically Deposited ZnO Thin Films.” J. Korean Phys. Soc. 55: 2476-81.
[4] Sun, S., Jiao, S., Zhang, K., Wang, D., Gao, S., Li, H. and et al. 2012. "Nucleation Effect and Growth Mechanism of $\mathrm{ZnO}$ Nanostructures by Electrodeposition from Aqueous Zinc Nitrate Baths." J. Cryst. Growth 359: 15-9.

[5] Ezenwa, I. A. 2012. "Synthesis and Optical Characterization of Zinc Oxide Thin Film." Res. J. Chem. Sci. 2: 26-30.

[6] Zhang, B. P., Wakatsuky, K., Binh, N.T., Usami, N. and Segawa, Y. 2004. Thin Solid Films 449: 12.

[7] Kim, T. W., Kwack, K. D., Kim, H. -K., Yoon, Y. S., Bahang, J. H. and Park, H.L. 2003. Solid State Commun. 127: 635 .

[8] Martinez, M. A., Herrero, J. and Gutierrez, M. T. 1997. Sol. Energy Mater. Sol. Cells 45: 75.

[9] Sun, X. W. and Kwok, H. S. 1999. J. Appl. Phys. 86 (1): 408.

[10] Chen, Y., Bagnall, D. M., Koh, H. -J., Park, K. -T., Hiraga, K., Zhu, Z. and et al. 1998. J. Appl. Phys. 84: 3912.

[11] Mohammad, M. T., Hashim, A. A. and Al-Maamory, M. H. 2006. Mater. Chem. Phys. 99: 382.

[12] Liu, Z.F., Jin, Z.G., Li, W. and Qiu, J. J. 2005. Mater. Lett. 
59: 3620 .

[13] Lincot, D. 2005. Thin Solid Films 487: 40.

[14] Kemell, M., Dartigues, F., Ritala, M. and Leskela, M. 2003. Thin Solid Films 434: 20.

[15] Liang, H. W., Lu, Y. M., Shen, D. Z., Yan, J. F., Li, B. H., Zhang, J. Y. and et al. 2005. J. Cryst. Growth 278: 305.

[16] Aghamalyan, N. R., Gambaryan, A., Goulanian, E. K., Hovsepyan, R. K., Kostanyan, R. B., Petrosyan, S. I. and et al. 2003. Semicond. Sci. Technol. 18: 525.

[17] Elias, J., Tena-Zaera and Levy-Clement, R. 2007. Thin Solid Films 515: 8553

[18] Guanglong, Z., Wexiang, C., Run, L. and Zudhe, X. 2007. Mater. Lett. 61: 4305.

[19] Chander, R. and Raychaudhuri, A. K. 2008. Solid State Commun. 145: 81.
[20] Altıkka, B., Baykul, M. C. and Altıokka, M. R. 2013. "Some Physical Effects of Reaction Rate on PbS Thin Films Obtained by Chemical Bath Deposition." J. Cryst. Growth 384: 50-4.

[21] Berruet, M. and Vazquez, M. 2010. "Electrodeposition of Single and Duplex Layers of $\mathrm{ZnO}$ with Different Morphologies and Electrical Properties." Mater. Sci. Semicond. Process. 13: 239-44.

[22] Orhan, N. and Baykul, M. C. 2012. "Characterization of Size-Controlled $\mathrm{ZnO}$ Nanorods Produced by Electrochemical Deposition Technique." Solid-State Electron. 78: 147-50.

[23] Kathalingam, A., Kim, M. R., Chae, Y. S. and Rhee, J. K. 2009. "Studies on Electrochemically Deposited ZnO Thin Films.” J. Korean Phys. Soc. 55: 2476-81. 